\title{
The Profile of COVID-19 Exposure in Healthcare Workers in Department of Medical Rehabilitation National General Hospital Cipto Mangunkusumo
}

\author{
Luh Karunia Wahyuni*, Widjajalaksmi Kusumaningsih, Melinda Harini, Steven Setiono, \\ Rizky Kusuma Wardhani, Peggy Sunarjo, Budiati Laksmitasari \\ Medical Rehabilitation Department, Faculty of Medicine, Universitas Indonesia - National General Hospital Cipto Mangunkusumo, Jakarta, \\ Indonesia
}

\author{
Email address: \\ luhkwahyuni@gmail.com (L. K. Wahyuni) \\ ${ }^{*}$ Corresponding author
}

\section{To cite this article:}

Luh Karunia Wahyuni, Widjajalaksmi Kusumaningsih, Melinda Harini, Steven Setiono, Rizky Kusuma Wardhani, Peggy Sunarjo, Budiati Laksmitasari. The Profile of COVID-19 Exposure in Healthcare Workers in Department of Medical Rehabilitation National General Hospital Cipto Mangunkusumo. Science Journal of Clinical Medicine. Vol. 10, No. 2, 2021, pp. 65-71. doi: 10.11648/j.sjcm.20211002.18

Received: June 8, 2021; Accepted: June 21, 2021; Published: June 26, 2021

\begin{abstract}
Background: Healthcare workers are a population groups at high risk of contracted by COVID-19 and some of the rehabilitation team involved in some therapeutic measures that produce the aerosol that further increase the chances of exposure to COVID-19. This study aims to assess the profile of COVID-19 exposure in healthcare worker in medical rehabilitation department National General Hospital Cipto Mangunkusumo. Methods: The study has been done in August 2020 to February 2021. The research subjects were all the healthcare workers who have met the inclusion and exclusion criteria. The data was collected from the questionnaires. Results: There were 289 cases involved, mostly women (74.4\%) and the resident doctors (59.2\%). The average age was 36 years. The subjects who had comorbidities were $41.2 \%$. The highest source of exposure came was the interaction among the healthcare workers $(85.1 \%)$ in the locations that they were usually gathered $(65.4 \%)$. The suitability of protective personal equipment only $70.6 \%$. Conclusion: The profile of COVID-19 exposure in healthcare worker among medical rehabilitation team in this hospital was dominated by young people, women, resident doctors, and without comorbidities. The pattern of the transmission dominated by interaction among the healthcare workers in area where they were gathered. It is hoped that this study can become the consideration in making policy regarding the transmission prevention among healthcare workers.
\end{abstract}

Keywords: COVID-19, Exposure, Healthcare Workers, Medical Rehabilitation Team, Transmission

\section{Introduction}

Coronavirus disease 2019 (COVID-19) is a group of symptoms consisting of cough, high fever and neck pain. COVID-19 is caused by a new type of Coronavirus which is named SARS-CoV-2. In December 2019, the virus began to spread in the city of Wuhan, China. Within a few months until April 2020, this virus has infected almost all countries in the world with a total of 3,400,000 confirmed cases and a total of 238,000 confirmed deaths. The World Health Organization (WHO) declared COVID-19 a pandemic in March 2020 [1, 2].

The number of confirmed cases in Indonesia in early May 2020 was 11,587 with a death case rate of 864 cases. This case has spread in 34 provinces in Indonesia. [3]

COVID-19 transmission process is through droplets from the mouth and nose that are released when someone with COVID-19 coughs, sneezes, or talks, especially if the other person is less than 1 meter away. This virus can also last quite a long time on inanimate surfaces, such as tables, door handles, or handrails. There will be a risk of infection if a healthy person holds the surface affected by these droplets and then touching their mouth, nose or eyes. Aerosol-producing medical measures, such as a nebulizer, effective cough exercises, etc., also increase the risk of spreading the virus. [1, 4].

COVID-19 has an incubation period up to 14 days to cause 
symptoms, some studies have shown a longer incubation period. Individuals with COVID-19 can transmit the virus to other individuals even though they do not have any symptoms. The symptoms of COVID- 19 are cough, fever, and shortness of breath, ranging from mild to severe, which can cause death. [1]

Healthcare workers are one of the high-risk group population of contracting COVID-19. This is due to high exposure from the patients, both symptomatic and non-symptomatic patients. Medical services such as consultations, dental care, installation of breathing aids, and others, increase the risk of health workers being exposed to COVID-19. Difficulties in obtaining adequate personal protective equipment (PPE) at the beginning of the pandemic also played a role in increasing the exposure of COVID-19 to healthcare workers. [4]

One of the healthcare worker population is the rehabilitation team that consists of physiatrists, resident doctors, physiotherapists, occupational therapists and speech therapists, orthotic prosthetic technicians, psychologists, and medical social workers. The medical rehabilitation team has a high probability exposure to patients with COVID-19 in both outpatient and inpatient settings. Some therapeutic measures such as nebulizer, effective cough exercise, chest physiotherapy, or breathing exercises can further increase the exposure of COVID-19 to the medical rehabilitation team. [5]

Standard recommendations for preventing the spread of infection including the application of Infection Prevention and Control (IPC) program while working in the health facilities. The implementation of the IPC strategy led the health services, including medical rehabilitation, to make an adjustment in providing medical services such as emphasizing to the therapeutic programs that can be done with or without the healthcare workers supervision. [6]

As a healthcare worker, the exposure of COVID-19 from our patients in hospital cannot be avoided but can be controlled by using PPE, handwashing before and after contact to the patient, and social distancing. The medical rehabilitation team in National General Hospital Cipto Mangunkusumo provides medical services for non-COVID-19 and COVID-19 patients both in outpatient and inpatient settings. Many preventions have been taken to prevent the spread of COVID-19 and protect its healthcare workers. Initial screening was carried out for all people that come into National General Hospital Cipto Mangunkusumo, especially patients with symptoms of upper respiratory tract infection. The procurement of PPE for healthcare workers, especially in the red zone which vulnerable to COVID-19 exposure has also been carried out according to a protocol adapted from WHO. Separation of COVID-19 treatment zones at Kiara unit (COVID -19 ward) is also one of the efforts in reducing the risk of COVID-19 transmission.

The medical rehabilitation department has also taken preventive steps to prevent the COVID-19 transmission, including socializing the use of PPE, procuring appropriate PPE, and reducing the medical services that can cause aerosols. All of this was done with the consideration that the quality of service must be maintained. However, exposure to COVID-19 in the Medical Rehabilitation team continued for several months even though all security protocols have been implemented. [7, 8]

The purpose of this study was to describe descriptively about the COVID-19 exposure to the medical rehabilitation team at National General Hospital Cipto Mangunkusumo as well as to analyze the other source of exposure and possible causes of exposure. All the authors hoped that better preventive action can be taken so that the medical rehabilitation team can perform medical rehabilitation services properly with a low risk of exposure.

\section{Method}

This study was descriptive analytic with cross sectional design and was performed at Medical Rehabilitation Department National General Hospital Cipto Mangunkusumo. The research subjects are all the healthcare worker that meets the inclusion and exclusion criteria. The sampling was done using consecutive sampling and the required sample size was 35 subjects.

The inclusion criteria were all the healthcare workers who gave medical rehabilitation services at the Medical Rehabilitation Department National General Hospital Cipto Mangunkusumo during the sampling period and was reported for confirmed case exposure. The exclusion criteria were healthcare workers who do not provide medical rehabilitation services (aged $>60$ years) or not willing to take part in this study.

The data were analyzed using the SPSS program for Windows version 22.0. Univariate analysis was carried out, which is descriptive analysis in the form of a description about the distribution of the characteristics of research subjects and research variables related to COVID-19.

\section{Results}

The number of case reports of healthcare workers exposed to COVID-19 in this study were 289 reports. The data included one healthcare worker who has exposed more than once so that the number obtained was more than the total number of health workers in the department. The total number of healthcare workers in medical rehabilitation department are 154 healthcare workers consisting of 70 employees and 84 resident doctors. Healthcare workers in this department are dominated by young age (under 60 years) with 150 healthcare workers were active in providing medical rehabilitation services during the pandemic. In this study, it was found that the average age of exposed health workers was 36 years. This is in line with studies by Guan et al (2020), Li et al (2020), and Sun et al (2020) who were found that the age group of healthcare workers infected with COVID -19 was a group of young workers (mean age 38.73 years). [9-11]

The gender of the most subjects were women by 215 people (74.4\%) with the most exposed professions was resident doctors by 171 people $(59.2 \%)$. The percentage of subjects 
with comorbidities was $41.2 \%$. The category of the comorbidities mostly other (stroke, allergic rhinitis, obesity, gastritis, and autoimmune diseases), which was $22.1 \%$. The characteristic of the subjects based on sociodemographic can be seen in table 1 .

Table 1. The Characteristics of Subjects based on Sociodemographic.

\begin{tabular}{|c|c|c|}
\hline \multicolumn{3}{|l|}{ Characteristic $(n=289)$} \\
\hline \multirow[t]{2}{*}{ Age (th) Mean \pm SD } & \multicolumn{2}{|c|}{$36.58 \pm 8.53$} \\
\hline & $\mathbf{n}$ & $\%$ \\
\hline \multicolumn{3}{|l|}{ Gender } \\
\hline Male & 74 & 25.6 \\
\hline Female & 215 & 74.4 \\
\hline \multicolumn{3}{|l|}{ Profession } \\
\hline Physical Medicine and Rehabilitation Specialists Doctor & 16 & 5.5 \\
\hline Nurse & 8 & 2.8 \\
\hline Physiotherapist & 43 & 14.9 \\
\hline Occupational therapist & 8 & 2.8 \\
\hline Speech therapist & 7 & 2.4 \\
\hline Orthotic Prosthetic technician & 2 & 0.7 \\
\hline Psychologist & 4 & 1.4 \\
\hline Others & 30 & 10.4 \\
\hline Pregnant & 5 & 1.7 \\
\hline Diabetes & 5 & 1.7 \\
\hline Hypertension & 21 & 7.3 \\
\hline Lung Disease & 24 & 8.3 \\
\hline Others & 64 & 22.1 \\
\hline
\end{tabular}

A systematic review study by Gholami $M$ et al. Shows that only $18.4 \%$ of health workers infected with COVID-19 have comorbidities (mostly hypertension). This is different from what was found in this study where subjects who had comorbidities were $41.2 \%$ with other categories of comorbidities (stroke, allergic rhinitis, obesity, gastritis, and autoimmune diseases), which was $22.1 \%$. Comorbidities among health workers is relatively small (less than 50\%) because the average age of health workers is still young but it turns out this figure is higher than the systematic study by Gholami $\mathrm{M}$ et al which collects 30 studies from different countries (China, USA, Netherlands, Italy, Germany, Switzerland and Spain).

Table 2. The Profile of Transmission Based on Source of Exposure, COVID-19 Case Criteria, Services at The Time of Exposure, Service Location, PPE, and PPE Suitability.

\begin{tabular}{|c|c|c|}
\hline & $\bar{n}$ & $\%$ \\
\hline \multicolumn{3}{|l|}{ Source of exposure } \\
\hline Patient & 30 & 10.4 \\
\hline Health workers & 246 & 85.1 \\
\hline Housemate & 11 & 3.8 \\
\hline Others & 1 & .3 \\
\hline \multicolumn{3}{|c|}{ Exposure source case criteria } \\
\hline Patient under monitoring & 155 & 53.6 \\
\hline Confirmed case & 134 & 46.4 \\
\hline \multicolumn{3}{|c|}{ Services at the time of exposure } \\
\hline Medical Consultation & 5 & 1.7 \\
\hline Exercise therapy & 12 & 4.2 \\
\hline Modalities & 1 & .3 \\
\hline Chest PT & 3 & 1.0 \\
\hline Others & 268 & 92.7 \\
\hline \multicolumn{3}{|l|}{ Service location } \\
\hline Polyclinic & 74 & 25.6 \\
\hline Wards & 24 & 8.3 \\
\hline Others & 189 & 65.4 \\
\hline \multicolumn{3}{|l|}{ PPE } \\
\hline Not using any PPE & 63 & 21.8 \\
\hline Level 1 PPE & 191 & 66.1 \\
\hline Level 2 PPE & 32 & 11.1 \\
\hline Level 3 PPE & 3 & 1.0 \\
\hline \multicolumn{3}{|l|}{ PPE Suitability } \\
\hline suitable & 204 & 70.6 \\
\hline not suitable & 53 & 18.3 \\
\hline not using PPE & 30 & 10.4 \\
\hline
\end{tabular}


As seen in table 2, it was found that the highest source of exposure came from among the healthcare workers, amounting to $85.1 \%$ with $53.6 \%$ criteria of exposure cases were under monitoring. During the exposure, $92.7 \%$ of the subjects were doing other activities than providing medical services (chatting, eating together, and work in the same room). The location of exposure mostly $(65.4 \%)$ was from other than medical service room (pantry, changing room, office room, and lecture room). Subjects wore PPE level 1 as much as $66.1 \%$ with the suitability of PPE and service location when exposed by $70.6 \%$.
Since the COVID-19 pandemic, new habits and new regulations have been enforced, especially regarding service flow, PPE, rotation of health workers, types of services, and follow-up for those exposed to COVID-19. The new rules and habits aim to reduce the spread of the risk of COVID-19 from patients to the health center and vice versa, from fellow health workers, and from health workers to people who live with the health worker. Based on the recommendations of the Gugus Tugas Percepatan Penanganan COVID-19, PPE according to the level of protection and location of service delivery can be seen in table 3.

Table 3. PPE Recommendation according to the level of protection and location of service delivery.

\begin{tabular}{|c|c|c|c|}
\hline Level of Protection & Group & Location & Type of PPE \\
\hline $\begin{array}{l}\text { Level } 1 \text {, Health } \\
\text { workers and } \\
\text { supporting staff }\end{array}$ & $\begin{array}{l}\text { Doctors \& } \\
\text { nurses }\end{array}$ & $\begin{array}{l}\text { General Practice Points and non-aerosol-generating } \\
\text { activities, as well as general outpatient sections }\end{array}$ & $\begin{array}{l}\text { Surgical mask } 3 \text { ply } \\
\text { Scrubs } \\
\text { Disposable medical latex examination gloves }\end{array}$ \\
\hline $\begin{array}{l}\text { level II, Health } \\
\text { workers and } \\
\text { supporting staff }\end{array}$ & $\begin{array}{l}\text { Administrative } \\
\text { staff }\end{array}$ & $\begin{array}{l}\text { Come into the examination room without giving any direct } \\
\text { assistance } \\
\text { Administration room } \\
\text { Polyclinic room, examination patients with symptoms of } \\
\text { respiratory infection } \\
\text { Wards for COVID-19 patients } \\
\text { Accompanying patients with suspect \& probable } \\
\text { COVID-19 }\end{array}$ & $\begin{array}{l}\text { Surgical mask } \\
\text { Disposable medical latex examination gloves } \\
\text { Cloth mask } 3 \text { ply } \\
\text { Surgical Mask 3ply } \\
\text { Gown (at risk of getting any droplets) } \\
\text { Disposable medical latex examination gloves } \\
\text { Face shield (at risk of getting any droplets) } \\
\text { Headcap }\end{array}$ \\
\hline $\begin{array}{l}\text { Level III, Health } \\
\text { workers and } \\
\text { supporting staff }\end{array}$ & $\begin{array}{l}\text { Doctors \& } \\
\text { nurses }\end{array}$ & $\begin{array}{l}\text { Procedure room and surgery in patients with Suspect, } \\
\text { probable or confirmed COVID-19 } \\
\text { Activities that generate aerosols }\end{array}$ & $\begin{array}{l}\text { N95 mask or equivalent } \\
\text { Coverall / gown } \\
\text { Boots with shoe cover } \\
\text { face shield } \\
\text { Sterile medical examination gloves } \\
\text { Headcap } \\
\text { Apron }\end{array}$ \\
\hline
\end{tabular}

The medical services provided by the Medical Rehabilitation Department in this hospital mostly in the non-COVID zone. The non-COVID zone is an area / room with a low risk of COVID-19 transmission because it is not directly related to COVID-19 patient services. The use of PPE in this zone can follow the Technical Instructions for the Use of PPE in dealing with COVID-19 (table 3). In addition, there is also a protocol for healthcare workers before go to the hospital (ensuring that they are in healthy condition; if they were sick, they should immediately go to the health facility, reporting to the chairman and resting at home until recovering; not wearing any jewelry or other accessories in the hospital; always wearing a mask; preparing their own hand sanitizer; using the safest transportation and keeping distances from others), when in hospital (entering the hospital through a different door from the patient / visitor door; changing personal clothes with hospital clothes for those who will make contact with the patient; wash hands with soap and running water for 40 to 60 seconds or with a hand sanitizer for 20 to 30 seconds; always use a surgical mask when working), and after working at the hospital (taking a shower and wearing clean clothes if the officer works in a room exposed to COVID-19 patients; always wear a mask; wash hands with soap and running water for 40 to 60 seconds or with a hand sanitizer for 20 to 30 seconds; and keep social distancing for more than 1 meter) $[13,14]$.
Along with its development, there is also a development health service innovation system in the form of telemedicine. Telemedicine providing remote health services by health professionals using information and communication technology, including information exchange for diagnosis, treatment, prevention of disease and injury, research and evaluation, and education of health service providers to improve the health of individuals and communities. The purpose of telemedicine is to reduce the number of cases of health workers infected with COVID-19, reduce face-to-face contact with patients except in emergency cases, limiting distance between individuals, control the number of hospital visits, provide information communication and education related to diet, lifestyle healthy and psychological support to carry out self-isolation, and direct referral to the hospital when needed. The Telemedicine method can be carried out in the form of online writing, voice, and / or video mode directly to obtain the necessary information by using the telemedicine application in the context of establishing a diagnosis, as well as patient management and treatment in accordance with statutory provisions. [14]

Hence, the Medical Rehabilitation Department National General Hospital has established and implemented several new rules and habits:

The rotation schedule of all health workers who are directly involved in the special service for COVID-19 patients (Kiara) 
which is Specialist, resident, and physiotherapist is scheduled to alternate every two weeks. Health workers scheduled to provide services in Kiara did not provide services in the department to prevent contamination in the department.

Types of high-risk services, like those containing or producing aerosols are eliminated, such as nebulization, pulmonary function examinations using spirometry and a peak flow meter, as well as other aerosol-producing therapies.

Provide a tele-rehabilitation services for consultation, education, and monitoring the exercise therapy.

A high-risk staff (more than 60 years old) are working from home

Residents who do not have the obligation to provide services are sent home and conduct lectures through the online system.

Coordination meetings, Resident's scientific events and exams that do not involve patients are carried out through the online system.

Face-to-face scientific events are held with a rule that the number of participants is $<50 \%$ of room capacity, prioritized for teaching skills / psychomotor skills, and still using PPE and implementing social distance.

A patient assessment / evaluation system was replaced with a portfolio evaluation to reduce unnecessary patient contact.

Research sites and research interventions were modified to reduce the risk of spreading COVID-19 infection. Example: aerosol-producing interventions or measuring instruments are replaced by aerosol-generating non-aerosols through the manufacture of amendments to the research protocol.

The level of PPE provided according with the location of the service. For example: outpatient services are required to wear PPE level 1, non-COVID inpatients are required to wear PPE level 2, and inpatients specifically for COVID patients are required to wear PPE level 3.

Provision of sterilization installations and ultraviolet light and disinfectant for the cleanliness of all rooms in the department.

Modify the elevator and chair facilities in the waiting room in order to implement a social distancing system.

For health workers who are exposed to contact tracing, they are not allowed to provide services for a while until a decision is made by the special team from the hospital.

Although the medical rehabilitation department have already established and implemented the new rules and habits based on the guideline, in this study, it was found that the highest source of exposure came from among the healthcare workers themselves $(85.1 \%)$. The highest exposure $(92.7 \%)$ came from activities other than providing medical services (chatting, eating together, coordinating to provide services, and one work space among healthcare worker). Location of exposure $65.4 \%$ came from others than medical services room (dining room, changing room, office room, and lecture room). Subjects mostly $(66.1 \%)$ wearing personal protective equipment (PPE) level 1 and those who did not wear PPE were $21.8 \%$ with the suitability of PPE and service location zone category was $70.6 \%$. Currently, many studies have shown that appropriate PPE is one of the most important and cost-effective ways to prevent the COVID-19 transmission among healthcare workers especially who was exposed by COVID-19 through contact and respiratory droplets or aerosols. [15]

In this study, it was found that 236 healthcare workers $(81.7 \%)$ were exposed to asymptomatic case criteria. All exposed healthcare workers did not undergo the Rapid Test, only 81 subjects $(28 \%)$ underwent PCR examinations as recommended by the special team National General Hospital Cipto Mangunkusumo for COVID-19. As many as 257 healthcare workers $(88.9 \%)$ were not recommended for self-isolation so they continued their job as usual. All of this data can be seen in table 4 .

Table 4. The Subject Description Based on COVID-19 Case Criteria, Clinical Symptoms, Rapid Test, PCR Test, and Follow Up.

\begin{tabular}{lll}
\hline & $\mathbf{n}$ & $\mathbf{\%}$ \\
\hline Case Criteria & & \\
asymptomatic & 236 & 81.7 \\
under monitoring & 37 & 12.8 \\
confirmed case & 16 & 5.5 \\
Clinical symptoms & & \\
asymptomatic & 257 & 88.9 \\
mild & 30 & 10.4 \\
moderate & 2 & 0.7 \\
Rapid Test & 0 & 0 \\
PCR Test & & \\
Positive & 31 & 10.7 \\
Negative & 50 & 17.3 \\
Not done & 208 & 72.0 \\
Follow up & & \\
Not isolated & 257 & 88.9 \\
Self-isolation & 30 & 10.4 \\
Hospitalized in a referral hospital & 2 & 0.7 \\
\hline
\end{tabular}

This is in line with research by Berkant Ozturk, et al. Found that mostly healthcare workers infected with COVID-19 are asymptomatic and recover without requiring special treatment. Several studies state that COVID-19 infection usually causes no symptoms or only shows mild symptoms. However, the elderly and comorbid individuals are at risk for severe and life-threatening symptoms (respiratory failure, ischemic stroke, or myocardial involvement). [16-21]

All the subjects in this study did not undergo a Rapid Test. The special team that was responsible for contact tracing of exposed healthcare workers consists of the Human Resources Unit who was responsible for contract tracing of exposed medical staff and administrative staffs; the Educational Coordinating Board team responsible for contact tracing of exposed resident doctors; Nursing Section responsible for contact tracing of exposed nurses; and the Service Support Unit team responsible for contact tracing of exposed therapists, psychologist, and orthosis prosthesis technicians. The special team only recommended 81 people ( $28 \%$ subjects) to do PCR examination. The positive results of COVID-19 infection were obtained from 31 people ( $10.7 \%$ of all case reports) and all were without symptoms. As many as 257 people (88.9\%) were recommended not to do self-isolation and continue their job. 


\section{Conclusion}

The profile of COVID-19 exposure in healthcare worker in the Medical Rehabilitation Department National General Hospital Cipto Mangunkusumo was dominated by young people, women, resident doctors, and without comorbidities. The pattern of the transmission mostly by interaction among the healthcare workers in area where they were gathered. It is hoped that the results of this study can become the consideration in making policy for medical rehabilitation services in the future in National General Hospital Cipto Mangunkusumo and other hospitals in Indonesia.

\section{Abbreviations}

Coronavirus-19=COVID-19

World Health Organization=WHO

Personal Protective Equipment $=\mathrm{PPE}$

Infection and Prevention Control=IPC

Ethics Approval and Consent to Participate

KET-504/UN. 2. F1/ETIK/PPM. 00.02/2020

\section{Competing Interest}

The authors declare that they have no competing interests.

\section{Availability of Data and Materials}

The sources of data or information used in this study from the human resource unit.

\section{Authors' Contribution}

LKW, WK, MH, SS, RKW, PS, and BL conceptualized, designed and prepared the initial draft and framework and interpreted the data.

\section{Acknowledgements}

This research is funded by Ministry of Research and Technology Indonesia.

\section{References}

[1] Li Q, Guan X, Wu P, et al. Early transmission dynamics in Wuhan, China, of novel coronavirus-infected pneumonia. N Engl J Med 2020; 382: 1199-207.

[2] World Health Organization. Coronavirus disease 2019 (COVID-19) situation report 100. Available at: https://www.who.int/docs/default-source/coronaviruse/situatio n-reports/20200429-sitrep-100-COVID-19.pdf?sfvrsn=bbfbf3 d1_2. Diakses 4 Mei 2020.

[3] Gugus Tugas Percepatan Penanganan COVID-19 Infografis 4 Mei 2020. Terdapat pada: https://COVID19.go.id/p/berita/infografis-COVID-19-4-mei-2 020. Diakses 4 Mei 2020.
[4] World Health Organization. Rational use of personal protective equipment (PPE) for coronavirus disease (COVID-19). terdapat pada: https://apps.who.int/iris/bitstream/handle/10665/331498/WHO -2019-nCoV-IPCPPE use-2020.2-eng.pdf. Diakses 4 Mei 2020 .

[5] Koh GC, Hoenig H. How should the rehabilitation comunity prepare for 2019-nCoV?. Archives of physical medicine and rehabilitation 2020.

[6] Kementerian Kesehatan RI Direktorat Jenderal Pencegahan Dan Pengendalian Penyakit (P2P). Pedoman pencegahan dan pengendalian coronavirus disease (COVID-19) revisi ke-4. 2020 .

[7] Aljadi SH, Al-Shemmari M, Al-Ramzi J, et al. Bacterial contamina- tion in physical therapy departments in the State of Kuwait. J Phys Ther Sci 2017; 29: 1014-8.

[8] Spratt HG Jr, Levine D, Bage J, Giles DK, Collier AG. Topical lotions utilized in outpatient rehabilitation clinics as a potential source of bacterial contamination. Physiother Theory Pract 2019; 35: 163-70.

[9] Guan W, Ni Z, Hu Y, Liang W, Ou C, He J, et al. Clinical characteristics of coronavirus disease 2019 in China. N Engl J Med 2020; 382 (18): 1708-20.

[10] Li K, Wu J, Wu F, Guo D, Chen L, Fang Z, et al. The clinical and chest $\mathrm{CT}$ features associated with severe and critical COVID-19 pneumonia. Invest Radiol 2020; 55 (6): 327-31.

[11] Sun P, Qie S, Liu Z, Ren J, Li K, Xi J. Clinical characteristics of hospitalized patients with SARS-CoV-2 infection: a single arm meta-analysis. J Med Virol 2020; 92 (6): 612-7.

[12] Mandana Gholami, Iman Fawad, Sidra Shadan, Rashed Rowaiee, HedaietAllah Ghanem, Amar Hassan Khamis, Samuel B. Ho. COVID-19 and healthcare workers: A systematic review and meta-analysis. International Journal of Infectious Diseases. Volume 104. 2021.pg 335-346.

[13] Indonesia COVID-19 Task Force (Gugus Tugas Percepatan Penanganan COVID-19). Personal Protective Equipment (PPE) Guide in Indonesia. Jakarta: Gugus Tugas Percepatan Penanganan COVID-19 BNPB; 2020.

[14] Ministry of Health Republic of Indonesia, Directory of Health Service. Technical Guide of Hospital Service in New Normal Adaptation Era. Jakarta: Ministry of Health Republic of Indonesia; 2020.

[15] Kalantary S, Et Al. Personal Protective Equipment For Protecting Healthcare Staff During COVID-19 Outbreak: A Narrative Review. Advanced Journal Of Emergency Medicine. 2020; 4 (2s): e61.

[16] Berkant Ozturk MD, Sema Ozturk MD, Ahmet Caglar MD, úllker Kacer MD, Muhammet Hacimustafaoglu MD, Kemal Ozturk MD. An Analysis of the impact of the COVID-19 pandemic on healthcare workers in a tertiary hospital in Turkey. Journal of Emergency Nursing. 2021.

[17] Oran DP, Topol EJ. Prevalence of Asymptomatic SARS-CoV-2 Infection: A Narrative Review. Ann Intern Med. 2020; 173 (5): 362-367.

[18] Jin H, Hong C, Chen S, et al. Consensus for prevention and management of coronavirus disease 2019 (COVID-19) for neurologists. Stroke Vasc Neurol. 2020; 5 (2): 146-151. 
[19] Long B, Brady WJ, Koyfman A, Gottlieb M. Cardiovascular complications in COVID-19. Am J Emerg Med. 2020; 38 (7): 1504-1507.

[20] Zhou F, Yu T, Du R, et al. Clinical course and risk factors for mortality of adult inpatients with COVID-19 in Wuhan, China: a retrospective cohort study Lancet. 2020; 395 (10229): 1054-1062.
[21] Grasselli G, Pesenti A, Cecconi M. Critical Care Utilization for the COVID-19 Outbreak in Lombardy, Italy: Early Experience and Forecast During an Emergency Response. JAMA. 2020; 323 (16): 1545-1546. 